\title{
The ethyl acetate fraction of corn silk exhibits dual antioxidant and anti-glycation activities and protects insulin-secreting cells from glucotoxicity
}

Chia-Chuan Chang ${ }^{1+}$, Wei Yuan ${ }^{2 \dagger}$, Hsiao-Yuh Roan ${ }^{3}$, Jia-Ling Chang ${ }^{4}$, Hsiu-Chen Huang ${ }^{5}$, Yu-Ching Lee ${ }^{6,7}$, Huey Jen Tsay ${ }^{8}$ and Hui-Kang Liu ${ }^{4,9^{*}}$

\begin{abstract}
Background: In this study, we aimed to develop a Stigmata Maydis (corn silk) fraction with dual bio-activities against oxidative stress and protein glycation to protect $\beta$-cells from diabetes-induced failure.

Methods: Corn silk fractions were prepared by partition and chemically characterised by thin-layer chromatography. Free radical scavenging assay, glycation assay, and cell-based viability test (neutral red) were employed to decide the best fraction. Cell death analysis was executed by annexin V/ Propidium iodide staining. Cell proliferation was measured by WST-1. Finally, $\beta$-cell function was evaluated by $\beta$-cell marker gene expression (RT-PCR) and acute insulin secretion test.

Results: Four corn silk fractions were prepared from an ethanolic crude extract of corn silk. In vitro assays indicate ethyl acetate fraction (YMS-EA) was the most potent fraction. YMS-EA also attenuated the hydrogen peroxide- or methylglyoxal-induced induction of reactive oxygen species, reduction of cell viability, and inhibition of cell proliferation. However, YMS-EA was unable to prevent hydrogen peroxide-induced apoptosis or advanced glycation end-products-induced toxicity. Under hyperglycemic conditions, YMS-EA effectively reduced ROS levels, improved mRNA expression of insulin, glucokinase, and PDX-1, and enhanced glucose-stimulated insulin secretion. The similarity of bioactivities among apigenin, luteolin, and YMS-EA indicated that dual activities of YMS-EA might be derived from those compounds.
\end{abstract}

Conclusions: We concluded that YMS-EA fraction could be developed as a preventive food agent against the glucotoxicity to $\beta$-cells in Type 2 diabetes.

Keywords: Stigmata Maydis (corn silk), Glucotoxicity, Methylglyoxal, Advanced glycation end products, Reactive oxygen species, $\beta$-cell failure

\footnotetext{
* Correspondence: hk.liu@nricm.edu.tw

${ }^{\dagger}$ Equal contributors

${ }^{4}$ Division of Basic Chinese Medicine, National Research Institute of Chinese

Medicine, Ministry of Health and Welfare, Taipei, Taiwan, ROC

${ }^{9}$ Ph.D Program for the Clinical Drug Discovery from Herbal Medicine, College

of Pharmacy, Taipei Medical University, Taipei, Taiwan, ROC

Full list of author information is available at the end of the article
} 


\section{Background}

Maize is known as corn which is widely grown in the Americas. In the United States alone, approximately 332 million metric tons of corn are grown annually [1]. Corn silk (Stigmata Maydis) is the female part of the corn. Although corn silk is often processed as agriculture waste, it is actually consumed as tea or regarded as an herb in traditional medicine. The main medicinal property of corn silk is to promote fluid excretion and reduce swelling [2]. In addition to its use as a natural diuretic, pharmacological studies of corn silk revealed antioxidant and anti-glycation activities that are used in diabetes, nephritis, or hypertension therapy [3]. In terms of chemical constituents related to these bio-activities, flavonoids such as luteolin, formononetin and apigenin are identified from Stigmata Maydis and their antioxidant properties have been illustrated [4-7]. Additionally, polysaccharides of Stigmata Maydis have been shown to reduce blood glucose and protein glycation in diabetic mice $[8,9]$.

Under physiological conditions, reactive oxygen species (ROS) and protein glycation are important molecules and essential biochemical events in the human body. However, excessive ROS or accumulated advanced glycation end-products (AGEs) may lead to tissue damage and aging [10]. For instance, diabetes is a complex metabolic disease with hyperglycaemia resulting from either insulin deficiency (Type 1 diabetes) or impaired insulin action and insulin secretory function (Type 2 diabetes) [11]. When diabetes is not well controlled, chronic hyperglycaemia leads to the progression of various diabetic complications via oxidative stress and AGE formation [12].

The loss of $\beta$-cell function and mass observed in uncontrolled diabetes may also be owing to glucotoxicity. Due to low levels of antioxidant enzymes, pancreatic $\beta$ cells are susceptible to oxidative stress via the production of excessive ROS under hyperglycaemic conditions [13]. As a result, glucotoxicity causes insulin secretory dysfunction and increased $\beta$-cell apoptosis, thus initiating a vicious cycle for glycaemic control [14, 15]. Moreover, low-level inflammation and additional oxidative stress from AGEs may affect $\beta$-cell proliferation and survival, thereby promoting $\beta$-cell failure [16].

Using corn silk constituents that possess both antioxidant and anti-glycation bio-activities, we aimed to generate a corn silk extract fraction that combines both activities to provide protective effects against glucotoxicity in insulin-secreting cells.

\section{Methods}

\section{Extraction and partition of Stigmata Maydis}

Stigmata Maydis was purchased from a Fu-Ji Chinese Traditional Medicine Store in Taipei on November 2008. Voucher specimens were deposited with the Herbarium of the National Research Institute of Chinese Medicine (NHP-00351). The ethanol extract (YMS) was made by extracting the dried material of Stigmata Maydis $(6 \mathrm{~kg}$ ) with $100 \mathrm{~L}$ of $95 \%$ ethanol at $55^{\circ} \mathrm{C}$ for $7 \mathrm{~h}$. Each fraction was made by partitioning the water suspended YMS (135 g) with corresponding solvents, such as $n$-hexane (Hex), ethyl acetate (EA), $n$-butanol $(\mathrm{BuOH})$, to yield YMS-Hex, $-\mathrm{BuOH},-\mathrm{EA}$, and -W fractions, respectively (Fig. 1a). Each YMS fraction and three flavonoid compounds, including apigenin (A), formononetin (F), and luteolin (L), were applied on a Merck thin-layer chromatography plate (Silica gel $60 \mathrm{~F}_{254}, 0.25 \mathrm{~mm}$ ) (Darmstadt, Germany) under the development in a mobile phase of $\mathrm{CHCl}_{3}$ and $\mathrm{MeOH}$ (8.5:1.5). Afterwards, separated spots were sprayed with anisaldehyde spray reagent and detected after ultraviolet absorption at $254 \mathrm{~nm}$ and $365 \mathrm{~nm}$.

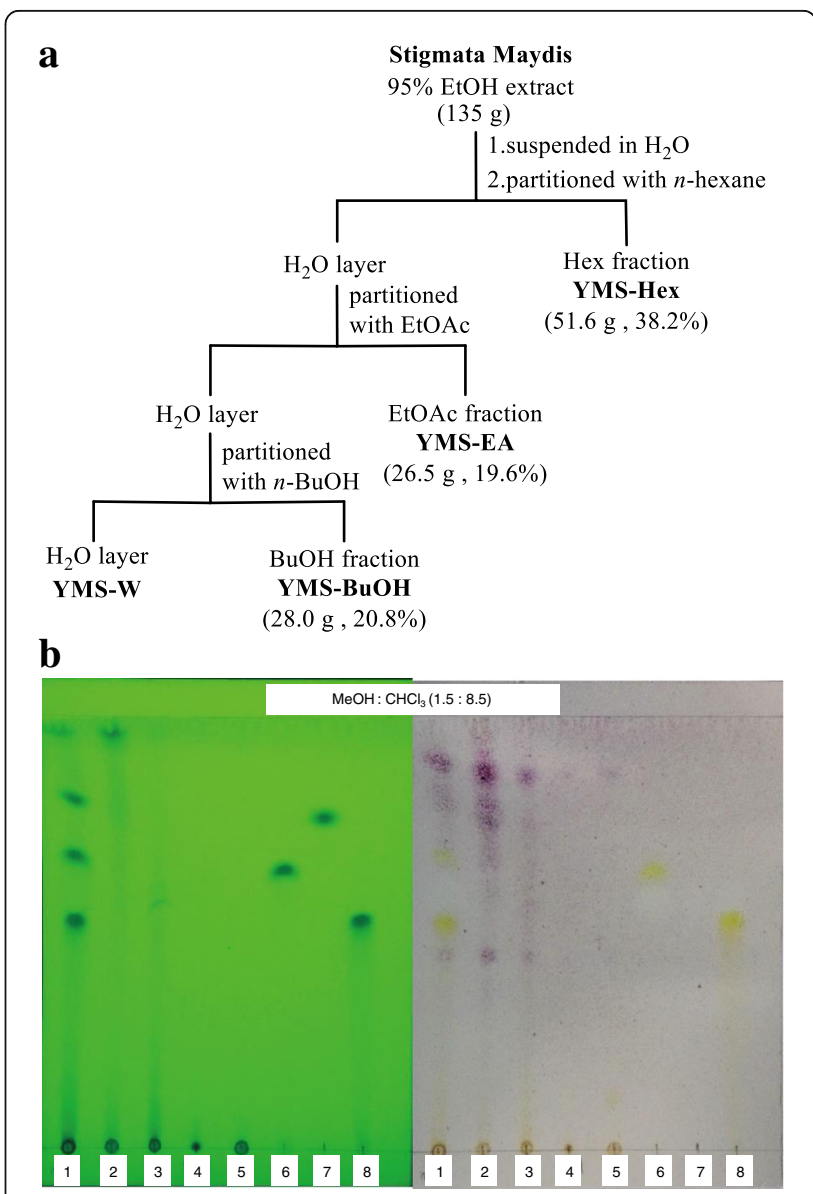

Fig. 1 Four YMS Fractions (YMS-Hex, $-\mathrm{BuOH},-E A,-W$ ) partitioned from the ethanol extract of Stigmata Maydis (YMS) with chemical characterisation by thin-layer chromatography (TLC). a The scheme of the preparation process for four YMS fractions from corn silk (Stigmata Maydis) crude extract. The estimated dry weight and yield of each fraction (except for YMS-W) are listed in parentheses. $\mathbf{b}$ A representative TLC chromatography of mixed sample (Mix; lane 1), four YMS fractions (-Hex, $-\mathrm{EA},-\mathrm{BuOH},-\mathrm{W}$; lane 2-5), and three flavonoid compounds (apigenin, formononetin, luteolin; lane 6-8) 


\section{ABTS free radical scavenging assay}

2,2'-azino-bis (3-ethylbenzthiazoline-6-sulfonic acid) (ABTS) was used for the measurement of antioxidant activity. Briefly, a reaction mix consisting of potassium persulfate $(2.45 \mathrm{mM})$ in ABTS solution $(7 \mathrm{mM})$ was prepared and kept in the dark at room temperature for at least $16 \mathrm{~h}$ before use. The intensively-coloured $\mathrm{ABTS}^{+}$solution was then diluted with $0.01 \mathrm{M}$ phosphate buffered saline (PBS) to give a $\mathrm{pH}$ of 7.4 with an absorbance of 0.70 at $734 \mathrm{~nm}$. The Stigmata Maydis fractions were diluted $100 \times$ with the $\mathrm{ABTS}^{+}$solution to a total volume of $1 \mathrm{ml}$. Absorbance was measured at 6 min after the addition of test reagents. A negative control was made with PBS instead of $\mathrm{ABTS}^{+}$solution. The $\%$ inhibitions by different concentrations of samples were calculated according to the following equation: $\left[1-\left(\mathrm{Abs}_{\text {sample }}+\mathrm{ABTS}^{+}{ }_{\text {solution }} / \mathrm{Abs}_{\mathrm{ABTS}}{ }^{+}{ }_{\text {solution }}\right) \times 100\right][17]$.

\section{Bovine serum albumin (BSA)-methylglyoxal (MG) assay and AGE preparation}

This assay was used to evaluate protein glycation, and BSA fluorescence levels were measured. Briefly, BSA $(10 \mathrm{mg} / \mathrm{ml})$ was non-enzymatically glycated via incubation in $1 \mathrm{M}$ PBS, $\mathrm{pH} 7.4$, at $37{ }^{\circ} \mathrm{C}$ for 7 days in the presence of $1 \mathrm{mM}$ MG and $3 \mathrm{mM}$ sodium azide. The Stigmata Maydis fractions were tested at concentrations of $0.01,0.02,0.05,0.1$, and $1.0 \mathrm{mg} / \mathrm{ml}$. Fluorescence of the samples was measured at the excitation and emission wavelengths of 335 and $385 \mathrm{~nm}$, respectively, versus a blank containing the protein and MG. The \% inhibition by different concentrations of samples was calculated according to the following equation:

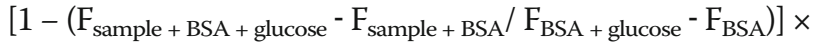
100. Aminoguanidine (AG) was used as a positive control.

The reactant under control condition was collected to generate AGEs through the dialysis and lyophilisation process. Products were kept at $-80{ }^{\circ} \mathrm{C}$ for cell-based studies.

\section{Cell culture}

The clonal rat pancreatic $\beta$-cell line (BRIN-BD11) was kindly provided by prof. PR Flatt at Univiersity of Ulster, Coleraine, UK and routinely grown as a monolayer in culture dishes at $37{ }^{\circ} \mathrm{C}$ under $5 \% \mathrm{CO}_{2}$ /air with $90 \%$ humidity. Cells were maintained in RPMI 1640 medium containing $10 \%$ foetal bovine serum and $5 \%$ penicillin and streptomycin mixture.

\section{Cell viability assay (neutral red)}

The cell viability assay was performed as previously described [18]. Briefly, at the end of cell treatments, the medium was replaced with the neutral red solution and incubated for another $2 \mathrm{~h}$. Quantification of the uptake of the neutral red by functional lysosomes in cells was spectrophotometrically measured at $540 \mathrm{~nm}$.

\section{Cell proliferation assay (WST-1)}

The WST-1 cell proliferation assay was performed according to the manufacture's protocol (Cayman Chemical). Briefly, cells were seeded on 96-well plates and the culture medium was replaced with various conditioned medium for $48 \mathrm{~h}$. At the end of treatment, the WST-1 reagent was added and incubated for another $2 \mathrm{~h}$. Finally, the plate was directly measured for absorbance at $450 \mathrm{~nm}$.

\section{Spectrofluorometric measurement of intracellular ROS} Intracellular ROS were measured by the CM$\mathrm{H}_{2}$ DCFDA assay. Cells were cultured at $37{ }^{\circ} \mathrm{C}$ with various conditions which were described in figure legends. After $24 \mathrm{~h}$, medium was replaced with the peroxide sensitive fluorescent probe, 5,6-dicarboxy2,7-dichlorodihydro fluorescein diacetate (carboxy$\mathrm{H}_{2}$ DCFDA; $20 \mu \mathrm{M}$ ), for an additional $30 \mathrm{~min}$ at $37^{\circ} \mathrm{C}$. The cells were then solubilised with $1 \%$ SDS and $5 \mathrm{mM}$ Tris $\mathrm{HCl}(\mathrm{pH}$ 7.4). The fluorescence intensity of the lysate was determined using a spectrofluorometer with excitation and emission wavelengths of $495 \mathrm{~nm}$ and $517 \mathrm{~nm}$, respectively.

\section{Flow cytometry with annexin V/Propidium iodide (PI) staining}

BRIN-BD11 cells were treated as mentioned above. Afterwards, they were trypsinised, pelleted, and resuspended in culture medium at a concentration of $1 \times$ $10^{6}$ cells $/ \mathrm{ml}$. After transferring $0.5 \mathrm{ml}$ of the cell suspension to a new tube, $10 \mu \mathrm{l}$ media binding reagent and $1.25 \mu \mathrm{l}$ annexin V-FITC were added. Following gentle vortexing, the mixture was incubated for $15 \mathrm{~min}$ at room temperature in the dark. After centrifuging at $1000 \mathrm{xg}$ for $5 \mathrm{~min}$ at room temperature, media was removed and $0.5 \mathrm{ml}$ of cold $1 \times$ binding buffer and $10 \mu \mathrm{l}$ propidium iodide were added. Following gentle vortexing, the sample was analysed on the flow cytometer within a $1 \mathrm{~h}$ period. The percentages of apoptotic and necrotic cells for each sample were estimated [19].

\section{Gene expression analysis}

BRIN-BD11 cells were seeded on $6 \mathrm{~cm}$-dish $\left(5 \times 10^{5}\right.$ cells/dish) and cultured under the condition described in Figure legends. At the end of experiments, total RNA were extracted and reverse transcribed. $50 \mathrm{ng}$ of complementary (c)DNA of each sample was used for later polymerase chain reaction (PCR). Respective primer sequence, annealing temperature, and size of PCR product of each gene was listed below. Beta- 
actin: For 5'-CGTAAAGACCTCTATGCCAA-3' and Rev 5'-AGCCATGCCAAATGTGTCAT-3'; $57{ }^{\circ} \mathrm{C}$; 349b.p. Glucokinase: For 5'-AAGGGAACTACATCG TAGGA-3' and Rev 5' -CATTGGCGGTCTTCATAGTA3 ; $57{ }^{\circ} \mathrm{C}$; 130b.p. pancreatic and duodenal homeobox-1 (PDX-1): For 5' ${ }^{\prime}$ CTCGCTGGGAACGCTGGAACA-3' and Rev 5'-GCTTTGGTGGATTTCATCCACGG-3'; $55{ }^{\circ} \mathrm{C}$; 225b.p. Insulin: For 5'-TGCCCAGGCTTTTGT CAAACAGCACCTT-3' and Rev 5'-CTCCAGTGC CAAGGTCTGAA-3'; $52{ }^{\circ} \mathrm{C}$; 187b.p. PCR products were separated by ethidium bromide stained gel electrophoresis, visualized, photographed with a digital camera, and quantified with Genetools 3.06 (Syngene, Frederick, MD, USA) [20].

\section{Insulin secretion}

BRIN-BD11 cells were plated on 24 -well plates $\left(0.5 \times 10^{5}\right.$ cells/well) and incubated for $48 \mathrm{~h}$ with media containing 5.6 or $30.0 \mathrm{mM}$ glucose. Then, after $1 \mathrm{~h}$ of preincubation with $1.1 \mathrm{mM}$ glucose, cells were challenged either with $1.1 \mathrm{mM}$ or with $16.7 \mathrm{mM}$ glucose in KrebsRinger Bicarbonate Buffer for $20 \mathrm{~min}$. The media were collected for insulin determination. Insulin concentrations were quantified by the Homogeneous TimeResolved Fluorescence (HTRF) insulin assay and normalized to a million of total cell numbers [21].

\section{Statistical analysis}

Data were presented as mean \pm standard error of the mean. Statistical analyses were performed using GraphPad Prism (GraphPad, CA, USA). Single parameterbased comparisons were obtained from the unpaired student's $t$-test. $P$ values less than 0.05 and 0.01 were considered to be significant. Multiparametric comparisons were performed using one-way ANOVA, followed by post-hoc analyses by Tukey's HSD protected least significant difference.

\section{Results}

\section{Chemical characterization of four YMS fractions}

\section{partitioned from an ethanolic crude extract of corn silk}

As shown in Fig. 1b, all fractions and the three flavonoid compounds were individually developed on a single TLC plate. In addition, all samples were pooled and cospotted on the same position on the $1^{\text {st }}$ lane (Mix). According the polarity of the solvents for extraction, the $R_{\mathrm{f}}$ values of all the detected compounds were distributed among the ranges of Hex (0.71 to 0.91), EA (0.52-0.71), $\mathrm{BuOH}(0.01$ to 0.52$)$ and $\mathrm{H}^{2} \mathrm{O}(0.0$ to 0.01$)$ fractions. The $R_{\mathrm{f}}$ values for two (apigenin and luteolin) of the three flavonoid compounds (apigenin: 0.66; formononetin: 0.74; luteolin: 0.57 ) were in the range of the YMS-EA fraction.
The ethyl acetate fraction (YMS-EA) most potently scavenges free radicals in vitro and protects against effects of $\mathrm{H}_{2} \mathrm{O}_{2}$ on $\beta$-cells

All fractions exhibited dose-dependent free radical scavenging effects (Fig. 1a). However, the effect of YMS-EA was superior to that of YMS-Hex, $-\mathrm{BuOH}$, and $-\mathrm{W}(p<$ 0.001), as it provided $75 \%$ inhibition at a concentration of $100 \mu \mathrm{g} / \mathrm{ml}$. Therefore, we chose YMS-EA as the major fraction and compared its effects with those of other test agents. First, to compare the protective effects of YMS fractions and reference drugs on $\mathrm{H}_{2} \mathrm{O}_{2}$-mediated ROS production and $\beta$-cell death, BRIN-BD11 cells were treated with $\mathrm{H}_{2} \mathrm{O}_{2}(125 \mu \mathrm{M})$ in the presence of YMS fractions $(100 \mu \mathrm{g} / \mathrm{ml}), \mathrm{AG}(2 \mathrm{mM})$, metformin (Met; $100 \mu \mathrm{M}$ ), or trolox (Trox; $100 \mu \mathrm{M}$ ) for $24 \mathrm{~h}$.

As shown in Fig. 2b, there is nearly a three-fold increase in ROS levels in $\mathrm{H}_{2} \mathrm{O}_{2}$-treated BRIN-BD11 cells. The presence of YMS-EA significantly decreased ROS levels in $\mathrm{H}_{2} \mathrm{O}_{2}$-treated BRIN-BD11 cells. Comparing YMS-EA with other test agents, only YMS-Hex, YMS$\mathrm{W}$, and Trox exhibited similar activities. In addition, there was a $50 \%$ reduction in the viability of $\mathrm{H}_{2} \mathrm{O}_{2}$ treated BRIN-BD11 cells after $24 \mathrm{~h}$ (Fig. 2c). YMS-EA significantly improved the cell viability of $\mathrm{H}_{2} \mathrm{O}_{2}$-treated BRIN-BD11 cells. YMS-Hex, YMS-W, AG, Met, and Trox provided similar protective effects.

YMS-EA and reference drugs attenuate the effects of acute $\mathrm{H}_{2} \mathrm{O}_{2}$ treatment on proliferation in BRIN-BD11 cells In terms of the impact of acute $\mathrm{H}_{2} \mathrm{O}_{2}$ treatment on cell proliferation, BRIN-BD11 cells were transiently treated with $\mathrm{H}_{2} \mathrm{O}_{2}$ for $2 \mathrm{~h}$, and proliferation was monitored at $24 \mathrm{~h}$ post-treatment. The cell proliferation rate of BRINBD11 cells treated with $\mathrm{H}_{2} \mathrm{O}_{2}(125$ or $250 \mu \mathrm{M})$ dropped over $50 \%$ at $6 \mathrm{~h}$ post-treatment (Fig. 3a). At $24 \mathrm{~h}$ posttreatment, the cell proliferation ratio of BRIN-BD11 cells that were treated with the lower concentration of $\mathrm{H}_{2} \mathrm{O}_{2}$ $(125 \mu \mathrm{M})$ returned to original levels. After $48 \mathrm{~h}$, there was a $50 \%$ reduction in the proliferation of BRIN-BD11 cells that were treated with higher concentration of $\mathrm{H}_{2} \mathrm{O}_{2}(250 \mu \mathrm{M})$. Therefore, the effects of YMS-EA and reference drugs were tested in the presence of $250 \mu \mathrm{M} \mathrm{H} \mathrm{H}_{2} \mathrm{O}_{2}$.

After acute $\mathrm{H}_{2} \mathrm{O}_{2}$ challenge, the treatment with YMSEA or reference drugs insufficiently improved cell proliferation (Fig. 3b). YMS-EA had a better effect at $50 \mu \mathrm{g} /$ $\mathrm{ml}$ compare with that at $100 \mu \mathrm{g} / \mathrm{ml}$. However, all of the reference drugs performed better than $100 \mu \mathrm{g} / \mathrm{ml}$ YMSEA $(p<0.001)$.

According to the cell death analysis, the transient treatment of BRIN-BD11 cells with $\mathrm{H}_{2} \mathrm{O}_{2}$ for $2 \mathrm{~h}$ for BRIN-BD11 cells caused late apoptosis in a dosedependent manner at $24 \mathrm{~h}$ post-treatment. The apoptotic cell population reached $70 \%$ after $24 \mathrm{~h}$ when 


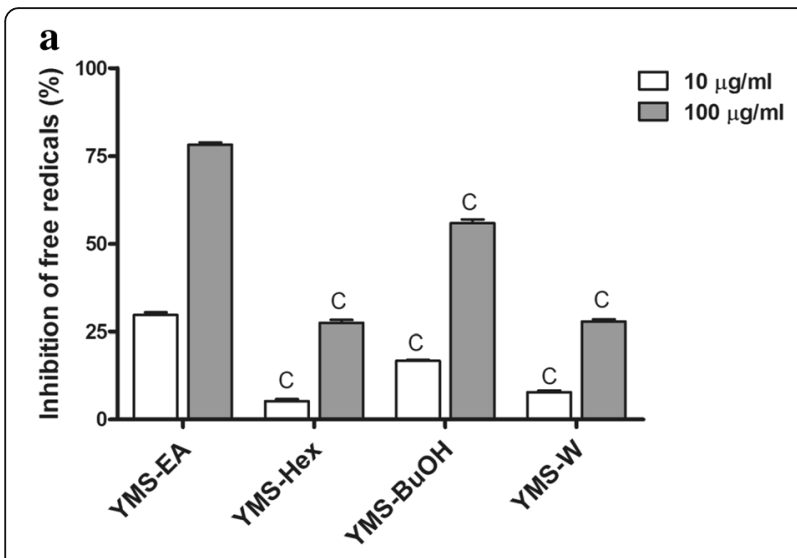

b

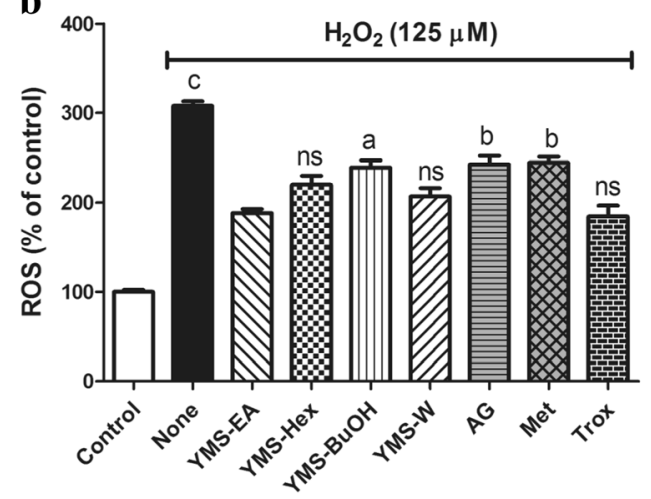

c

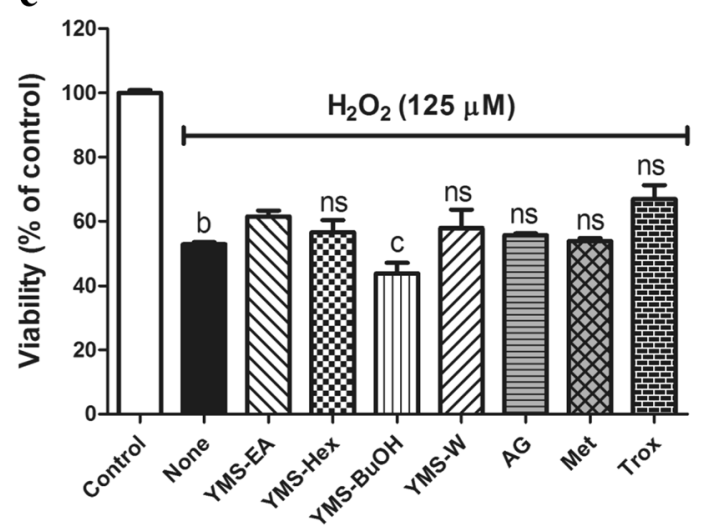

Fig. 2 Comparison of YMS fractions and reference drugs for bioactivities against ABTS- and $\mathrm{H}_{2} \mathrm{O}_{2}$-mediated free radical generation and $\mathrm{H}_{2} \mathrm{O}_{2}$ - induced cell death. a Free radical scavenging activities of YMS fractions. Data are mean \pm standard error of the mean (SEM); $n=3 .{ }^{c} p<0.001$ versus the corresponding YMS-EA group. b Inhibitory effects of YMS fractions $(100 \mu \mathrm{g} / \mathrm{ml})$, aminoguanidine (AG; $2 \mathrm{mM}$ ), metformin (Met; $100 \mu \mathrm{M}$ ), and trolox (Trox; $100 \mu \mathrm{M}$ ) on $\mathrm{H}_{2} \mathrm{O}_{2}(125 \mu \mathrm{M})$-induced ROS levels in BRIN-BD11 cells after 24 h. Data are mean \pm SEM $(n=5) .{ }^{a} p<0.05,{ }^{b} p<0.01,{ }^{c} p<0.001$ versus the YMS-EA group. $\mathbf{c}$ Viability of BRIN-BD11 cells that were treated with $\mathrm{H}_{2} \mathrm{O}_{2}(125 \mu \mathrm{M})$ for $24 \mathrm{~h}$ in the presence of YMS fractions, AG, Met, and Trox. Data are mean $\pm \operatorname{SEM}(n=5) .{ }^{b} p<$ 0.01 and ${ }^{c} p<0.001$ versus the YMS-EA group
BRIN-BD11 cells were transiently challenged with $250 \mu \mathrm{M} \mathrm{H}_{2} \mathrm{O}_{2}$ (Fig. 3c). Under this condition, treatment with YMS-EA or reference drugs had no effect (Fig. 3d).

\section{YMS-EA treatment ameliorates MG-mediated glycation, ROS production, and cell death}

The anti-glycation activity was determined by the production efficiency of fluorescent AGEs, which were generated by co-incubating BSA and MG (Fig. 4a). All YMS fractions inhibited the formation of AGEs in a dosedependent manner. At low concentrations $(10 \mu \mathrm{g} / \mathrm{ml})$, the inhibitory effect of YMS-EA was less effective than that of YMS-Hex and -BuOH. However, at high concentrations $(1000 \mu \mathrm{g} / \mathrm{ml})$, YMS-EA demonstrated the most effective anti-glycation activity when compared with YMS-Hex, $-\mathrm{BuOH}$, and -W $(p<0.01, p<0.001$, and $p<$ 0.001 , respectively).

As shown in Fig. 4b, MG $(800 \mu \mathrm{M})$-treated BRINBD11 cells exhibited three-fold increase in ROS levels after $24 \mathrm{~h}$. Treatment with $100 \mu \mathrm{g} / \mathrm{ml}$ YMS-EA significantly reduced ROS production. Similar effects were observed with YMS-W, Met, and Trox. AG appeared to be the most potent anti-glycation agent. Furthermore, after BRIN-BD11 cells were treated with $800 \mu \mathrm{M}$ MG for $24 \mathrm{~h}$, viability decreased by nearly $50 \%$ (Fig. 4c). In the presence of YMS-EA, there was a significant increase in the viability of BRIN-BD11 cells. Similar effects were observed with YMS-W, Met, and Trox. It is important to note that AG treatment elicited a nearly $100 \%$ protective effect in BRIN-BD11 cells.

\section{YMS-EA treatment has no protective effects on AGE- mediated cell death and anti-proliferation in BRIN-BD11 cells}

The presence of AGEs $(3 \mathrm{mg} / \mathrm{ml})$ in the culture medium significantly reduced viability at $48 \mathrm{~h}$ posttreatment $(p<0.05)$ (Fig. 5a). There was no difference in cell viability under this condition in the presence of YMS-EA (50 or $100 \mu \mathrm{g} / \mathrm{ml}$ ). Additionally, treatment with $3 \mathrm{mg} / \mathrm{ml}$ AGEs had a potent anti-proliferation effect on BRIN-BD11 cells $(p<$ 0.001). Surprisingly, instead of providing beneficial effects on cell proliferation, the presence of YMS-EA $(100 \mu \mathrm{g} / \mathrm{ml})$ significantly worsened cell proliferation $(p<0.05)$.

\section{Addition of YMS-EA attenuates the hyperglycaemia- induced elevation of ROS, reduction of $\beta$-cell marker genes, and impairment of glucose responsiveness in BRIN-BD11 cells}

Compared with cells cultured under $5.6 \mathrm{mM}$ glucose, cells cultured under $30 \mathrm{mM}$ glucose exhibited a 1.5-fold increase in ROS levels (Fig. 6a). The presence of YMSEA significantly suppressed the induction of ROS by 


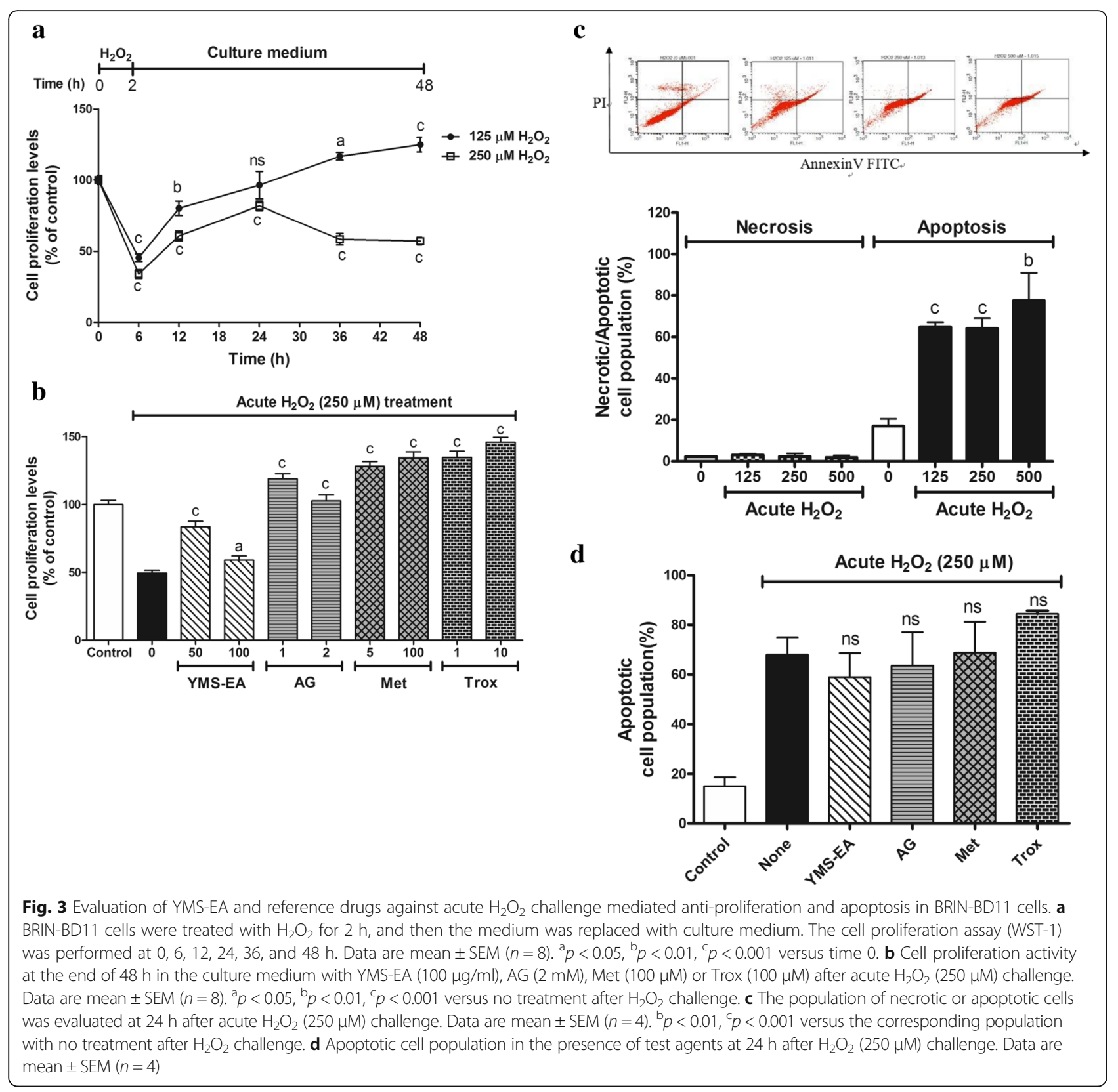

$30 \mathrm{mM}$ glucose $(p<0.01)$. Both concentrations of YMSEA were equally effective, whereas none of the reference drugs had ROS scavenging effects.

We further analysed the gene expression of $\beta$-cell markers in the presence of $5.6 \mathrm{mM}$ or $30 \mathrm{mM}$ glucose. There was a significant reduction in the mRNA levels of insulin, glucokinase, and pancreatic and duodenal homeobox-1 (PDX-1) (Fig. 6b). Consistently, the presence of YMS-EA attenuated this reduction in the mRNA levels of $\beta$-cell markers.

Finally, when BRIN-BD11 cells were cultured under $30 \mathrm{mM}$ glucose for $48 \mathrm{~h}$, the glucose responsiveness of
BRIN-BD11 cells was abolished (Fig. 6c). Treatment of $50 \mu \mathrm{g} / \mathrm{ml}$ YMS-EA restored insulin secretory activity in response to $16 \mathrm{mM}$ glucose $(p<0.01)$. However, this beneficial effect did not appear when $100 \mu \mathrm{g} / \mathrm{ml}$ YMSEA was used. Under the stimulated condition (16.7 mM glucose), the amount of insulin secreted from YMS-EA $(50 \mu \mathrm{g} / \mathrm{ml})$-treated BRIN-BD11 cells was significantly more $(p<0.01)$ than that from YMS-EA $(100 \mu \mathrm{g} / \mathrm{ml})$ treated cells. In contrast, in Fig. 6d, treatment of AG could only significantly enhanced insulin secretion under basal condition $(p<0.05)$ rather than stimulated condition. 


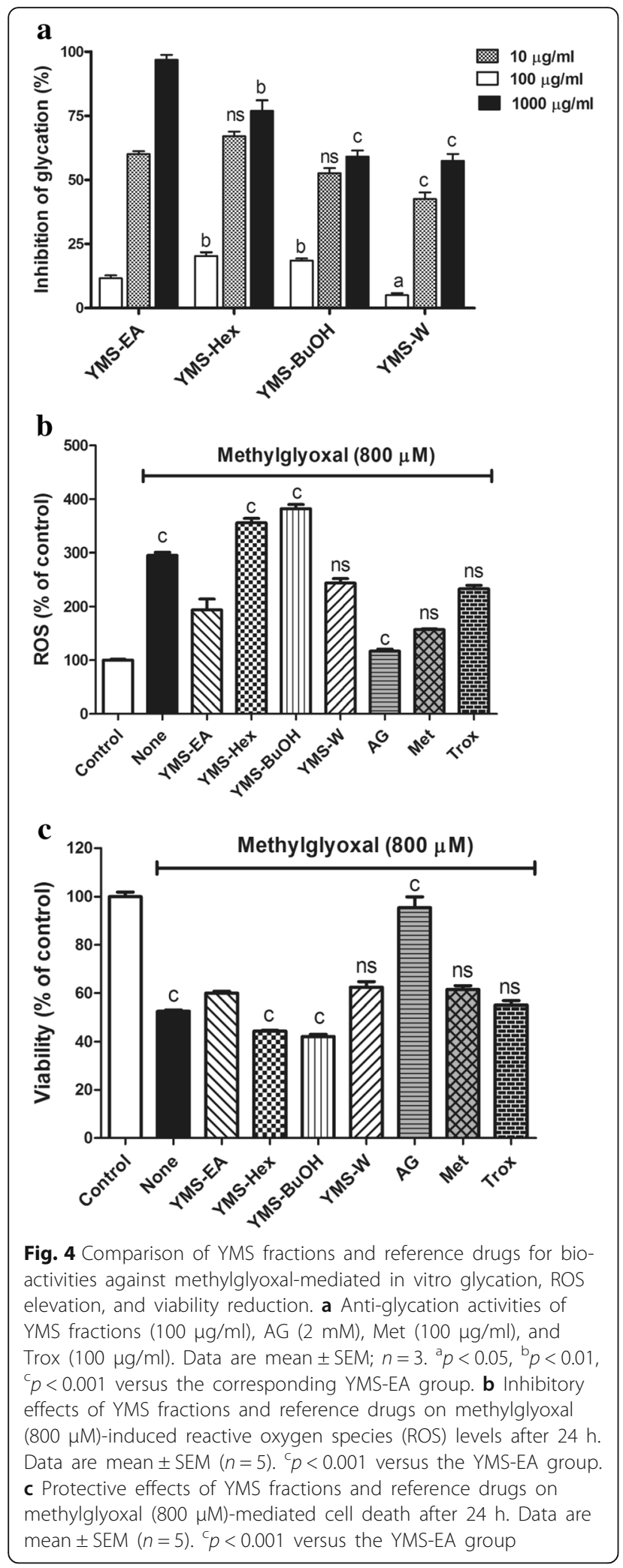

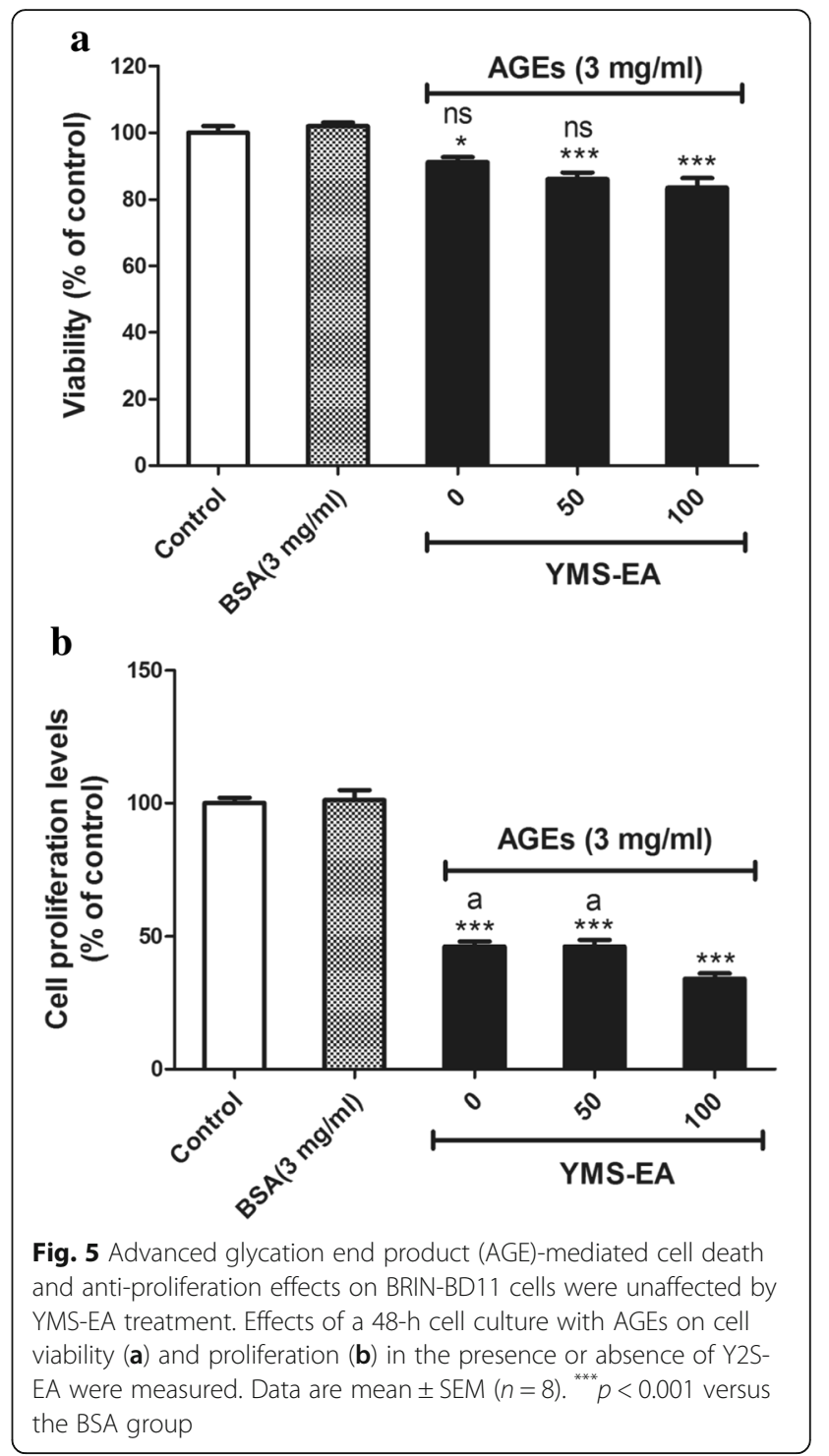

Individual effects of three flavonoid compounds on dual activities and beta-cell protection

By employing previous experiments, individual effects of apigenin (A), formononetin (F) and luteolin (L) were examined. In Fig. 7a, only apigenin and luteolin provided a dose-dependent protective effect on $\mathrm{H}_{2} \mathrm{O}_{2}$-induced bête-cell death. In terms of anti-AGE formation, only apigenin at $100 \mu \mathrm{M}$ can significantly inhibited AGE formation $(p<0.01)$. Furthermore, three flavonoids provided beta-cell protection against methylglyoxal. Formononetin appeared to be superior to other two (Fig. 7c). In terms of AGEs-inhibited cell proliferation, all flavonoids could provide beneficial effects. Instead, addition of apigenin and luteolin worsen the inhibitory effects of AGEs on cell proliferation. Finally, impaired glucose-responsiveness of hyperglycemia-damaged BRIN-BD11 cells was unable to be restored by three 

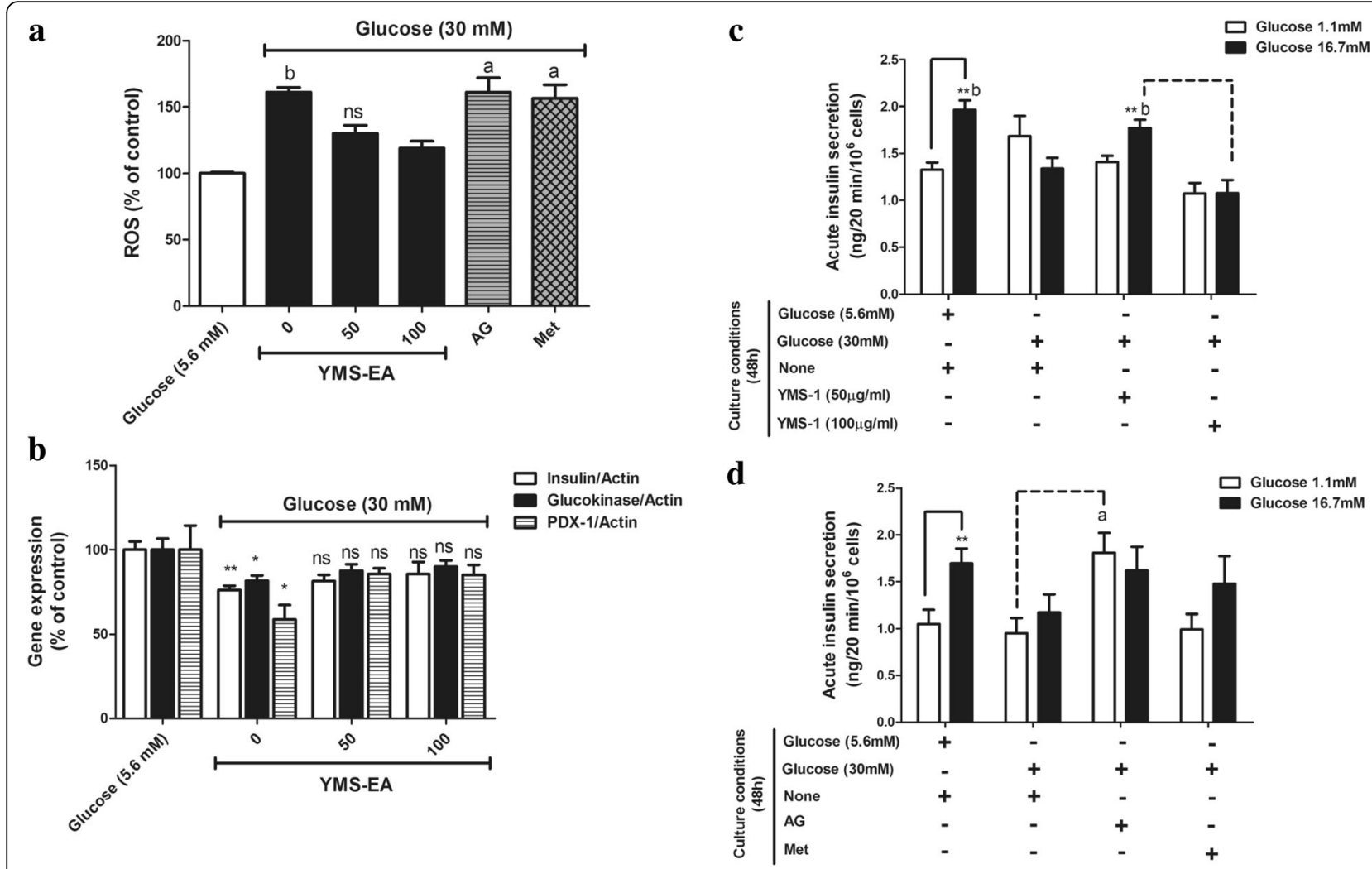

Fig. 6 Beneficial effects of YMS-EA on BRIN-BD11 cells in a high-glucose (30 mM) medium induced the generation of free radicals, the reduction of $\beta$-cell marker genes, and the impairment of glucose-induced insulin secretion. a Effects of YMS-EA, AG (2 mM), and Met (100 $\mu M$ ) on ROS levels in BRIN-BD11 cells cultured in high-glucose medium for $48 \mathrm{~h}$. Data are mean \pm SEM $(n=6)$. ${ }^{a} p<0.05$ and ${ }^{b} p<0.01$ versus the YMS-EA (100 $\mu \mathrm{g} / \mathrm{ml}$ ) group. $\mathbf{b}$ Effects of YMS-EA on the gene expression of insulin/glucokinase/ pancreatic and duodenal homeobox-1 (PDX-1) in BRIN-BD11 cells cultured in high-glucose medium for $48 \mathrm{~h}$. Data are mean \pm SEM $(n=4) .{ }^{*} p<0.05$ and ${ }^{* *} p<0.01$ versus the control culture condition $(5.6$ mM glucose). c Effects of YMS-EA on the glucose-responsiveness of BRIN-BD11 cells cultured in high-glucose medium for $48 \mathrm{~h}$. Data are mean \pm SEM $(n=8) .{ }^{* *} p<0.01$ versus the $1.1 \mathrm{mM}$ glucose group-under the same culture condition. ${ }^{\mathrm{b}} p<0.01$ versus the corresponding $\mathrm{YMS}$-EA (100 $\left.\mu \mathrm{g} / \mathrm{ml}\right)$ group. $\mathbf{d}$ Effects of AG and Met on the glucose-responsiveness of BRIN-BD11 cells cultured in high-glucose medium for $48 \mathrm{~h}$. Data are mean \pm SEM $(n=6) .{ }^{* *} p<0.01$ versus the $1.1 \mathrm{mM}$ glucose group-under the same culture condition. ${ }^{\mathrm{a}} p<0.05$ versus the corresponding condition of None (30 mM Glucose) group

flavonoids (Fig. 7d). However, addition of formononetin partially increased basal insulin secretion (Fig. 7e).

\section{Discussion}

Because a large amount of corn silk is treated as agriculture waste after the processing of corn, using a simple preparation process to develop a corn silk fraction with health benefits would promote the utilization of corn silk. In the present study, we aimed to make a fraction with dual bio-activities, including antioxidant and antiglycation activities. Aminoguanidine, trolox, and metformin are three reference drugs with single or dual activities against oxidative stress and glycation [22-25]. Our in vitro results indicate that the YMS-EA fraction was the most effective fraction. Although the YMS$\mathrm{BuOH}$ fraction was partitioned with $n$-butanol, which has the closest polarity index number compared to ethyl acetate, it exhibited significantly less bio-activity. The $R_{\mathrm{f}}$ values of apigenin and luteolin were in the range of YMS-EA suggested that both flavonoids may contribute to the dual bioactivity of YMS-EA. Luteolin derivatives were also previously identified from EA fraction [3]. Interestingly, two independent research publications showing that apigenin has activity to scavenge ROS and luteolin intervenes the formation of AGEs support our view $[6,26]$.

The islets are known to have relatively low levels of antioxidants, and decreases in blood glutathione levels contribute to the accumulation of ROS in the islet during diabetes. Thus, the application of an antioxidation mechanism to protect beta-cell survival and function is a long-accepted concept [27]. The employment of antioxidants is an important strategy for the preservation of $\beta$-cell function, as shown in several experimental and clinical studies $[28,29]$. Consistent with the above concept, our results demonstrate that YMS-EA possessed 

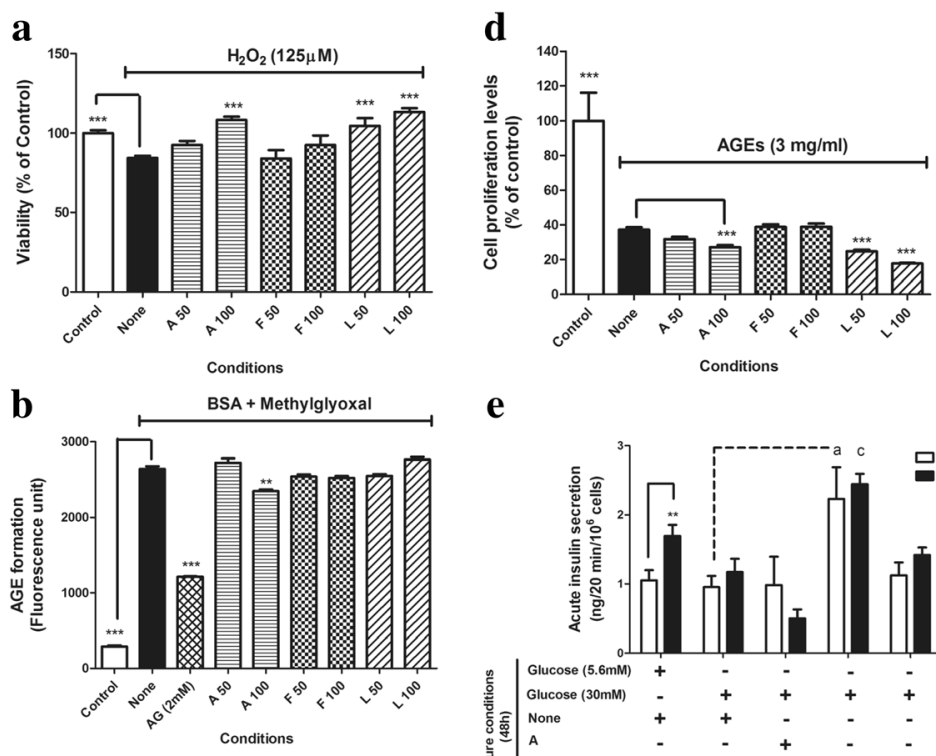

$\mathbf{e}$
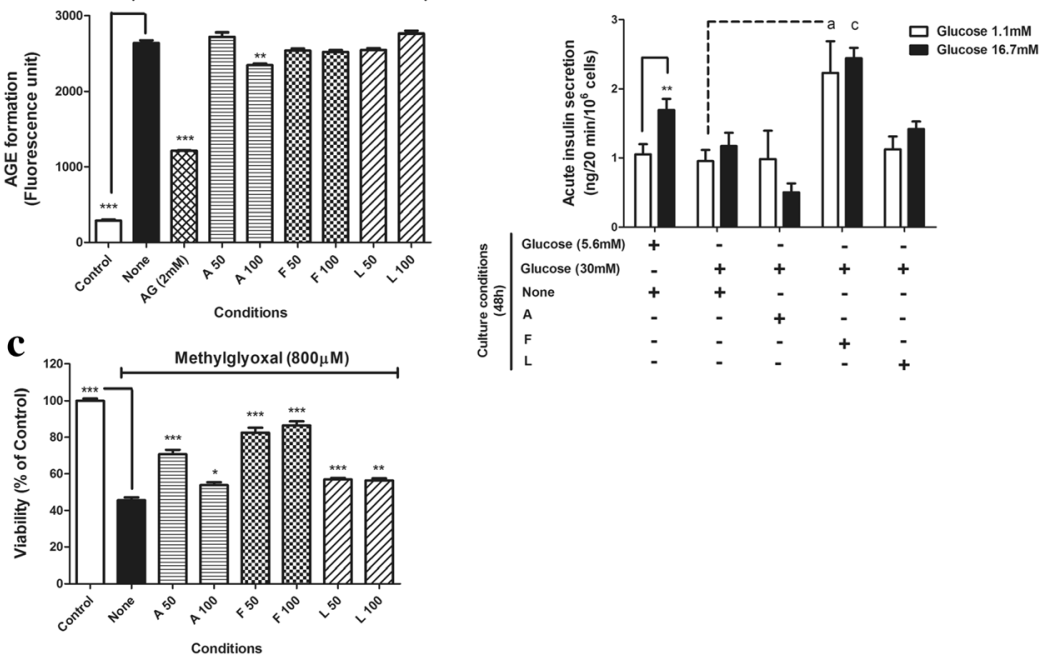

Fig. 7 Evaluation of dual activities and beta-cell protective effects of three flavonoids. To explore the activity relationship between YMS-EA and three flavonoids, we repeated following experiments by using three flavonoids $(\mu \mathrm{M})$. a $\mathrm{H}^{2} \mathrm{O}^{2}$ - induced cell death. Data are mean \pm SEM $(n=6)$. ${ }^{* * *} p<0.001$ versus the None group. b AGE formation assay. Data are mean $\pm \operatorname{SEM}(n=3) .{ }^{* * *} p<0.001$ versus the None group. c Methylglyoxalinduced cell death. Data are mean $\pm \operatorname{SEM}(n=12) .{ }^{*} p<0.05$ and ${ }^{* * *} p<0.001$ versus the None group. $\mathbf{d}$ AGEs inhibited cell proliferation assay. Data are mean $\pm \operatorname{SEM}(n=8)$. ${ }^{* *} p<0.001$ versus the None group. e Glucose stimulated insulin secretion of hyperglycemia damaged cells. Data are mean $\pm \operatorname{SEM}(n=6) .{ }^{* *} p<0.01$ versus the $1.1 \mathrm{mM}$ glucose group-under the same culture condition. ${ }^{\mathrm{a}} p<0.05$ and ${ }^{\mathrm{C}} p<0.001$ versus the corresponding condition of None (30 mM Glucose) group

free radical scavenging activity and improved BRINBD11 cell viability by reducing ROS production in the presence of $\mathrm{H}_{2} \mathrm{O}_{2}$. This activity of YMS-1 was better than that of $\mathrm{YMS}-\mathrm{BuOH}, \mathrm{AG}$, and Met. In addition, YMS-EA attenuated the anti-proliferative effect of acute $\mathrm{H}_{2} \mathrm{O}_{2}$ treatment on BRIN-BD11 cells. However, the application of reference drugs appeared to be more effective than YMS-EA. In contrast, the presence of YMS-EA and other reference drugs could not effectively prevent BRIN-BD11 cells from previously triggered apoptosis by $\mathrm{H}_{2} \mathrm{O}_{2}$. Therefore, the present study suggests that YMSEA and reference drugs are more suitable for the prevention or intervention of ROS-induced cell death. Similar to reference drugs, YMS-EA could not rescue $\mathrm{H}_{2} \mathrm{O}_{2}$-induced apoptotic cells. This was possibly because YMS-EA and reference drugs lack of the DNA repair activity against $\mathrm{H}_{2} \mathrm{O}_{2}$-induced DNA damages and subsequent apoptosis [20,30].

AGEs are generated from the nonenzymatic interaction between protein and carbohydrates and are regarded as important mediators of diabetes-related complications. AGEs also play a role in beta-cell failure in diabetes [16]. MG is a reactive compound that is derived from glucose and fructose metabolism. It is not only is a ROS donor but plays a role in AGE formation [31]. In the current study, a high concentration of YMSEA was the most effective at inhibiting MG-mediated AGE formation. However, only YMS-EA and YMS-W significantly inhibited MG-induced ROS production and improved cell survival in BRIN-BD11 cells. Among all test agents, AG was the most potent agent for the prevention of MG-mediated cell death. Our results also further indicate that YMS-EA could not provide any protection to enable $\beta$-cell survival against AGEmediated toxicity. Our findings suggest that YMS-EA has a preventive, but not rescue, effect on the loss of $\beta$ cell mass and function in diabetes.

Finally, we evaluated whether YMS-EA could prevent glucotoxicity-induced $\beta$-cell dysfunction. The excessive entry of glucose has been shown to elicit $\beta$-cell injury 
and increase the nonenzymatic glycation of cellular proteins in animal studies [32, 33]. A $\beta$-cell line cultured under high-glucose concentrations exhibits deteriorating outcomes in insulin, glucokinase, and PDX-1 expression [34-37]. Oxidative stress is also known to play an important role in high glucose-mediated $\beta$-cell dysfunction [38]. Interestingly, only YMS-EA could effectively reduce the level of ROS under high-glucose conditions. Such effect was associated with the restoration of the expression of important beta-cell marker genes. However, in terms of the insulin secretory function in response to glucose, the improvement in glucose responsiveness by $50 \mu \mathrm{g} / \mathrm{ml}$ YMS-EA treatment disappeared when $100 \mu \mathrm{g} / \mathrm{ml}$ YMSEA was used. In the future, an optimized dosage for YMS-EA should be carefully examined.

By examining activities of three flavonoids, results actually pointed out similarity between the actions of three flavonoids and YMS-EA. Consistent with the indication that YMS-EA might contain apigenin and luteolin type of flavonoids, both compounds provided strong antioxidant effects while apigenin could also prevent AGE formation. Interestingly, apigenin, luteolin, and YMS-EA at high dose worsen AGEs-inhibited cell proliferation. As a result, the dual effects of YMS-EA might be derived from collaboration of those compounds.

\section{Conclusions}

In conclusion, our study provides some basis to support the notion that Stigmata Maydis could be developed as a dietary agent to protect $\beta$-cell survival and function against pathological oxidative stress and protein glycation in diabetes.

\section{Abbreviations \\ ABTS: 2,2'-azino-bis (3-ethylbenzthiazoline-6-sulfonic acid); AGEs: Advanced glycation end-products; BSA: Bovine serum albumin; carboxy-H2DCFDA: 5,6- dicarboxy-2,7-dichlorodihydro fluorescein diacetate; HTRF: Homogeneous Time-Resolved Fluorescence; MG: Methylglyoxal; PBS: Phosphate buffered saline; PDX-1: Pancreatic and duodenal homeobox-1; PI: Propidium iodide; ROS: Reactive oxygen species}

\section{Acknowledgements}

BRIN-BD11 cells were kindly provided by Prof. Flatt, P.R. from University of Ulster, UK. Manuscript was edited by a native English editor from biosciencewriters.

\section{Funding}

This work was funded by the National Research Institute of Chinese Medicine, Ministry of Health and Welfare (Grant No. MM10501-0274) and Cheng Hsin General Hospital (Grant Number: Chgh-103-42).

\section{Availability of data and materials}

The datasets supporting the conclusions of this article are included within the article.

\section{Authors' contributions}

CCC, WY, HYR, and JLC carried out the study. HKL and CCC designed the experiments and supervised the work. HJT helped to analyzed and interpreted the data. HKL, CCC, and WY wrote the manuscript. $\mathrm{HCH}$ and $\mathrm{YCL}$ helped to provide research data for revise manuscript. All authors read and approved the final manuscript.

\section{Competing interests}

The authors declare that they have no competing interests.

\section{Consent for publication}

Not applicable in this section. This article is not a clinical study involving human participants.

\section{Ethics approval and consent to participate}

Not applicable in this section.

\section{Author details}

${ }^{1}$ School of Pharmacy, College of Medicine, National Taiwan University, Taipei, Taiwan, ROC. 'Department of Psychiatry, Cheng Hsin General Hospital, Taipei, Taiwan, ROC. ${ }^{3}$ Department of Life Sciences and Institute of Genome Sciences, National Yang-Ming University, Taipei, Taiwan, ROC. ${ }^{4}$ Division of Basic Chinese Medicine, National Research Institute of Chinese Medicine, Ministry of Health and Welfare, Taipei, Taiwan, ROC. ${ }^{5}$ Department of Applied Science, National Hsinchu University of Education, Hsinchu, Taiwan, ROC.

${ }^{6}$ The Center of Translational Medicine, Taipei Medical University, Taipei, Taiwan, ROC. ${ }^{7}$ The Ph.D. Program for Medical Biotechnology, College of Medical Science and Technology, Taipei Medical University, Taipei, Taiwan, ROC. ${ }^{8}$ Institute of Neuroscience, Brain Research Centre, National Yang-Ming University, Taipei, Taiwan, ROC. ${ }^{9}$ Ph.D Program for the Clinical Drug Discovery from Herbal Medicine, College of Pharmacy, Taipei Medical University, Taipei, Taiwan, ROC.

Received: 27 May 2016 Accepted: 7 October 2016

Published online: 03 November 2016

\section{References}

1. Nations FaAOotU. In: Division S, editor. Maize, rice and wheat: area harvested, production quantity, yield. 2009.

2. Hasanudin K, Hashim P, Mustafa S. Corn silk (Stigma maydis) in healthcare: a phytochemical and pharmacological review. Molecules (Basel, Switzerland). 2012;17(8):9697-715.

3. Ren SC, Ding XL. Study on determination methods of flavonoids from corn silk. Food Sci. 2004;25(3):139-42.

4. Yu TT, Lu XX, Lian XJ, Zhang YQ. Composition analysis of flavonoids from corn silk with thin-layer chromatography and ultraviolet spectrophotometry. Food Sci. 2008;29(11):477-81.

5. Silva MM, Santos MR, Caroco G, Rocha R, Justino G, Mira L. Structure-antioxidant activity relationships of flavonoids: a re-examination. Free Radic Res. 2002;36(11):1219-27.

6. Wu CH, Yen GC. Inhibitory effect of naturally occurring flavonoids on the formation of advanced glycation endproducts. J Agric Food Chem. 2005;53(8):3167-73.

7. Matsuda $H$, Wang T, Managi H, Yoshikawa M. Structural requirements of flavonoids for inhibition of protein glycation and radical scavenging activities. Bioorg Med Chem. 2003;11(24):5317-23.

8. Zhao WZ, Yu ZP, Yu YD, Liu BQ, Liu JB. Research progress of polysaccharides from Stigma maydis. Food Sci. 2010;31(11):289-92.

9. Suzuki R, Okada Y, Okuyama T. A new flavone C-glycoside from the style of Zea mays L. with glycation inhibitory activity. Chem Pharm Bull (Tokyo). 2003;51(10):1186-8.

10. Stefano GB, Challenger S, Kream RM. Hyperglycemia-associated alterations in cellular signaling and dysregulated mitochondrial bioenergetics in human metabolic disorders. Eur J Nutr. 2016. doi:10.1007/s00394-016-12122.

11. Lin Y, Sun Z. Current views on type 2 diabetes. J Endocrinol. 2010;204(1):1-11.

12. Ajith TA, Vinodkumar P. Advanced glycation end products: association with the pathogenesis of diseases and the current therapeutic advances. Curr Clin Pharmacol. 2016;11(2):118-27.

13. Brun T, Maechler P. Beta-cell mitochondrial carriers and the diabetogenic stress response. Biochim Biophys Acta. 2016;1863(10):2540-9.

14. Kharroubi I, Ladriere L, Cardozo AK, Dogusan Z, Cnop M, Eizirik DL. Free fatty acids and cytokines induce pancreatic beta-cell apoptosis by different mechanisms: role of nuclear factor-kappaB and endoplasmic reticulum stress. Endocrinology. 2004;145(11):5087-96.

15. Harmon JS, Stein R, Robertson RP. Oxidative stress-mediated, posttranslational loss of MafA protein as a contributing mechanism to loss of 
insulin gene expression in glucotoxic beta cells. J Biol Chem. 2005;280(12):11107-13.

16. Lim M, Park L, Shin G, Hong H, Kang I, Park Y. Induction of apoptosis of beta cells of the pancreas by advanced glycation end-products, important mediators of chronic complications of diabetes mellitus. Ann N Y Acad Sci. 2008:1150:311-5.

17. Boudouda HB, Zeghib A, Karioti A, Bilia AR, Ozturk M, Aouni M, Kabouche A, Kabouche Z. Antibacterial, antioxidant, anti-cholinesterase potential and flavonol glycosides of Biscutella raphanifolia (Brassicaceae). Pak J Pharm Sci. 2015;28(1):153-8.

18. Chen CC, Hsu CY, Chen CY, Liu HK. Fructus Corni suppresses hepatic gluconeogenesis related gene transcription, enhances glucose responsiveness of pancreatic beta-cells, and prevents toxin induced betacell death. J Ethnopharmacol. 2008;117(3):483-90.

19. Rieger AM, Nelson KL, Konowalchuk JD, Barreda DR. Modified annexin V/ propidium iodide apoptosis assay for accurate assessment of cell death. J Vis Exp. 2011;(50):2597.

20. Liu HK, McCluskey JT, McClenghan NH, Flatt PR. Iterative exposure of clonal BRIN-BD11 cells to ninhydrin enables selection of robust toxin-resistant cells but with decreased gene expression of insulin secretory function. Pancreas. 2008;36(3):294-301.

21. Stone VM, Dhayal S, Brocklehurst KJ, Lenaghan C, Sorhede Winzell M, Hammar M, Xu X, Smith DM, Morgan NG. GPR120 (FFAR4) is preferentially expressed in pancreatic delta cells and regulates somatostatin secretion from murine islets of Langerhans. Diabetologia. 2014;57(6):1182-91.

22. Adeshara K, Tupe R. Antiglycation and cell protective actions of metformin and glipizide in erythrocytes and monocytes. Mol Biol Rep. 2016;43(3):195-205.

23. Piro $S$, Rabuazzo AM, Renis M, Purrello F. Effects of metformin on oxidative stress, adenine nucleotides balance, and glucose-induced insulin release impaired by chronic free fatty acids exposure in rat pancreatic islets. J Endocrinol Invest. 2012;35(5):504-10.

24. Thornalley PJ. Use of aminoguanidine (Pimagedine) to prevent the formation of advanced glycation endproducts. Arch Biochem Biophys. 2003;419(1):31-40

25. Sharma SS, Sayyed SG. Effects of trolox on nerve dysfunction, thermal hyperalgesia and oxidative stress in experimental diabetic neuropathy. Clin Exp Pharmacol Physiol. 2006;33(11):1022-8.

26. Batra P, Sharma AK. Anti-cancer potential of flavonoids: recent trends and future perspectives. 3 Biotech. 2013;3(6):439-59.

27. Masuda Y, Vaziri ND, Li S, Le A, Hajighasemi-Ossareh M, Robles L, Foster CE, Stamos MJ, Al-Abodullah I, Ricordi C, et al. The effect of Nrf2 pathway activation on human pancreatic islet cells. PLoS One. 2015;10(6):e0131012.

28. Page KA, Reisman T. Interventions to preserve beta-cell function in the management and prevention of type 2 diabetes. Curr Diab Rep. 2013;13(2):252-60

29. Robertson RP, Harmon J, Tran PO, Tanaka Y, Takahashi H. Glucose toxicity in beta-cells: type 2 diabetes, good radicals gone bad, and the glutathione connection. Diabetes. 2003;52(3):581-7.

30. Onaran I, Guven GS, Ozdas SB, Kanigur G, Vehid S. Metformin does not prevent DNA damage in lymphocytes despite its antioxidant properties against cumene hydroperoxide-induced oxidative stress. Mutat Res. 2006;611(1-2):1-8.

31. Matafome P, Sena C, Seica R. Methylglyoxal, obesity, and diabetes, Endocrine. 2013;43(3):472-84.

32. Tajiri Y, Moller C, Grill V. Long-term effects of aminoguanidine on insulin release and biosynthesis: evidence that the formation of advanced glycosylation end products inhibits B cell function. Endocrinology. 1997;138(1):273-80

33. Mullokandov EA, Franklin WA, Brownlee M. DNA damage by the glycation products of glyceraldehyde 3-phosphate and lysine. Diabetologia. 1994;37(2):145-9.

34. Prentki M, Joly E, El-Assaad W, Roduit R. Malonyl-CoA signaling, lipid partitioning, and glucolipotoxicity: role in beta-cell adaptation and failure in the etiology of diabetes. Diabetes. 2002;51 Suppl 3:5405-13.

35. Robertson RP, Zhang HJ, Pyzdrowski KL, Walseth TF. Preservation of insulin mRNA levels and insulin secretion in HIT cells by avoidance of chronic exposure to high glucose concentrations. J Clin Invest. 1992;90(2):320-5.

36. Olson LK, Redmon JB, Towle HC, Robertson RP. Chronic exposure of HIT cells to high glucose concentrations paradoxically decreases insulin gene transcription and alters binding of insulin gene regulatory protein J Clin Invest. 1993:92(1):514-9.

37. Olson LK, Sharma A, Peshavaria M, Wright CV, Towle HC, Rodertson RP, Stein R. Reduction of insulin gene transcription in HIT-T15 beta cells chronically exposed to a supraphysiologic glucose concentration is associated with loss of STF-1 transcription factor expression. Proc Natl Acad Sci U S A. 1995;92(20):9127-31.

38. Tangvarasittichai S. Oxidative stress, insulin resistance, dyslipidemia and type 2 diabetes mellitus. World J Diabetes. 2015;6(3):456-80.

\section{Submit your next manuscript to BioMed Central and we will help you at every step:}

- We accept pre-submission inquiries

- Our selector tool helps you to find the most relevant journal

- We provide round the clock customer support

- Convenient online submission

- Thorough peer review

- Inclusion in PubMed and all major indexing services

- Maximum visibility for your research

Submit your manuscript at www.biomedcentral.com/submit
C Biomed Central 